\title{
Millipede and centipede (Myriapoda: Diplopoda, Chilopoda) assemblages in secondary succession: variance and abundance in Western German beech and coniferous forests as compared to fallow ground
}

\author{
A. Schreiner ${ }^{1}$, P. Decker ${ }^{2}$, K. Hannig ${ }^{3}$, and A. Schwerk ${ }^{1}$ \\ ${ }^{1}$ Laboratory of Evaluation and Assessment of Natural Resources, Warsaw University of Life Sciences - SGGW, \\ Nowoursynowska Street 166, 02-787 Warsaw, Poland \\ ${ }^{2}$ Department of Soil Zoology, Senckenberg Museum of Natural History Görlitz, Am Museum 1, \\ 02826 Görlitz, Germany \\ ${ }^{3}$ Freelance Naturalist, Dresdener Str. 6, 45731 Waltrop, Germany
}

Correspondence to: A. Schreiner (tapferes.schreinerlein@yahoo.de)

Received: 22 December 2011 - Revised: 14 March 2012 - Accepted: 2 April 2012 - Published: 2 May 2012

\begin{abstract}
Successional processes are an important element of commercial-forest ecosystems. They can be followed by studying the species composition of various animal groups, e.g. millipedes. Over the vegetation periods 2009 and 2010, we pitfall-trapped millipedes and centipedes (Myriapoda: Diplopoda, Chilopoda) on 21 Western German (North Rhine-Westphalian) deciduous and coniferous forest as well as fallow-ground sites of increasing age (1-165 yr) and determined them to the species and sex. Diplopoda (2009: 1659/2010: 3417 individuals) outnumbered the trapped Chilopoda (2009: 37/2010: 111 individuals) by far while the general catching results approximately doubled from 2009 to 2010. Indirect gradient analysis (CA) revealed that the influence of the habitat type on the formation of diplopod assemblages exceeded the influence of the successional stage. Although no clear trend in individual-count development over time occurred in most species detected, Julus scandinavius (Latzel, 1884) significantly increased in numbers with ageing of the deciduous (beech) forests. In conclusion, J. scandinavius may be a suitable bioindicator of deciduous-forest succession. More data are necessary to transfer our results into a mathematical function describing the course of increasing J. scandinavius abundance.
\end{abstract}

\section{Introduction}

Due to anthropogenous changes, e.g. in Germany, primeval beech forests retreated while monocultures strongly increased (Pott, 1995). Today's commercial forests thus mainly undergo successional processes as a complete ecosystem. This is accompanied by numerous changes in the number and composition of various animal groups of this ecosystem (Szyszko, 1983; Scheu and Schulz, 1996). Many alterations can be followed on the species level of, e.g. Carabidae and Diplopoda (Neumann, 1971; Schwerk, 2008).

In contrast to ground beetles (Carabidae), which are useful bioindicators for the state of succession (Schwerk, 2008;
Koivula, 2011), especially by showing a characteristic increase of the mean individual biomass over time (Szyszko, 1983; Schwerk and Szyszko, 2007; Schreiner, 2011), data on millipedes and centipedes (Myriapoda: Diplopoda, Chilopoda) over the run of succession are scarce. In postmining primary succession (Dunger and Voigtländer, 2009) as well as on floodplains (Zulka, 1991), only one true pioneer species (Chilopoda: Lamyctes emarginatus, Newport, 1844) was identified in nearly $50 \mathrm{yr}$ of observation. Millipedes and centipedes seem to generally need a rather long time for site immigration (Dunger and Voigtländer, 1990, 2009; Balkenhol et al., 2006; Voigtländer and Balkenhol, 2006), after which only saprophagous millipede species show a 
Table 1. Study sites and number of Myriapoda individuals over the vegetation periods 2009 and 2010: (a) beech, (b) Douglas fir, (c) spruce, and (d) fallow ground.

\begin{tabular}{|c|c|c|c|c|c|c|c|}
\hline \multicolumn{8}{|c|}{ (a) Beech } \\
\hline Site & $\begin{array}{l}\text { Age in } \\
2009(y r)\end{array}$ & $\begin{array}{l}\text { Size } \\
\text { (ha) }\end{array}$ & Byplants & $\begin{array}{l}\text { Ordinance } \\
\text { Survey Map }\end{array}$ & Groups & $\begin{array}{l}\text { No. } \\
2009\end{array}$ & $\begin{array}{l}\text { No. } \\
2010\end{array}$ \\
\hline \multirow[t]{2}{*}{ B1 } & 1 & 0.5 & Few larch \& cherry & $4609 / 1$ & Diplopoda & 100 & 297 \\
\hline & & & & & Chilopoda & 9 & 12 \\
\hline \multirow[t]{2}{*}{ B2 } & 1 & 0.9 & $5 \%$ cherry & $4609 / 1$ & Diplopoda & 11 & 12 \\
\hline & & & & & Chilopoda & 2 & 4 \\
\hline \multirow[t]{2}{*}{ B3 } & 3 & 0.5 & None & $4510 / 3$ & Diplopoda & 180 & 418 \\
\hline & & & & & Chilopoda & 5 & 11 \\
\hline \multirow[t]{2}{*}{ B4 } & 4 & 0.4 & None & $4609 / 1$ & Diplopoda & 77 & 111 \\
\hline & & & & & Chilopoda & 0 & 3 \\
\hline \multirow[t]{2}{*}{ B5 } & 13 & 1.6 & None & $4510 / 3$ & Diplopoda & 39 & 49 \\
\hline & & & & & Chilopoda & 4 & 4 \\
\hline \multirow[t]{2}{*}{ B6 } & 20 & 0.8 & None & $4609 / 1$ & Diplopoda & 62 & 113 \\
\hline & & & & & Chilopoda & 0 & 4 \\
\hline \multirow[t]{2}{*}{ B7 } & 26 & 1.8 & $10 \%$ larch & $4609 / 1$ & Diplopoda & 82 & 162 \\
\hline & & & & & Chilopoda & 0 & 4 \\
\hline \multirow[t]{2}{*}{ B8 } & 28 & 0.6 & Few larch \& cherry & $4609 / 1$ & Diplopoda & 71 & 200 \\
\hline & & & & & Chilopoda & 1 & 7 \\
\hline \multirow[t]{2}{*}{ B9 } & 52 & 2.2 & $10 \%$ larch & $4609 / 1$ & Diplopoda & 35 & 151 \\
\hline & & & & & Chilopoda & 1 & 5 \\
\hline \multirow[t]{2}{*}{ B10 } & 78 & 2.5 & $10 \%$ oak & $4609 / 1$ & Diplopoda & 64 & 253 \\
\hline & & & & & Chilopoda & 1 & 7 \\
\hline \multirow[t]{2}{*}{ B11 } & 146 & 1.0 & 10-yr-old beech & $4609 / 1$ & Diplopoda & 250 & 258 \\
\hline & & & & & Chilopoda & 1 & 5 \\
\hline \multirow[t]{2}{*}{ B12 } & 146 & 4.0 & None & $4609 / 1$ & Diplopoda & 147 & 134 \\
\hline & & & & & Chilopoda & 3 & 6 \\
\hline \multirow[t]{2}{*}{ B13 } & 152 & 3.5 & $10 \%$ oak & $4609 / 1$ & Diplopoda & 70 & 105 \\
\hline & & & & & Chilopoda & 2 & 1 \\
\hline \multirow[t]{2}{*}{ B14 } & 165 & 3.1 & None & $4609 / 1$ & Diplopoda & 61 & 327 \\
\hline & & & & & Chilopoda & 1 & 10 \\
\hline \multirow[t]{2}{*}{ Total } & & & & & Diplopoda & 1249 & 2590 \\
\hline & & & & & Chilopoda & 30 & 83 \\
\hline \multicolumn{8}{|c|}{ (b) Douglas fir } \\
\hline Site & $\begin{array}{l}\text { Age in } \\
2009(y r)\end{array}$ & $\begin{array}{l}\text { Size } \\
\text { (ha) }\end{array}$ & Byplants & $\begin{array}{l}\text { Ordinance } \\
\text { Survey Map }\end{array}$ & Groups & $\begin{array}{l}\text { No. } \\
2009\end{array}$ & $\begin{array}{l}\text { No. } \\
2010\end{array}$ \\
\hline \multirow[t]{2}{*}{ D1 } & 1 & 0.2 & None & $4510 / 3$ & Diplopoda & $9^{*}$ & $42^{*}$ \\
\hline & & & & & Chilopoda & $0^{*}$ & $2^{*}$ \\
\hline \multirow[t]{2}{*}{ D2 } & 3 & 0.2 & None & $4510 / 3$ & Diplopoda & $35^{*}$ & 196 \\
\hline & & & & & Chilopoda & $0^{*}$ & 6 \\
\hline \multirow[t]{2}{*}{ D3 } & 10 & 0.4 & None & $4510 / 3$ & Diplopoda & 26 & 49 \\
\hline & & & & & Chilopoda & 0 & 6 \\
\hline \multirow[t]{2}{*}{ D4 } & 30 & 0.5 & None & $4510 / 3$ & Diplopoda & 36 & 56 \\
\hline & & & & & Chilopoda & 1 & 6 \\
\hline \multirow[t]{2}{*}{ Total } & & & & & Diplopoda & 106 & 343 \\
\hline & & & & & Chilopoda & 1 & 20 \\
\hline
\end{tabular}


Table 1. Continued

\begin{tabular}{|c|c|c|c|c|c|c|c|}
\hline \multicolumn{8}{|c|}{ (c) Spruce } \\
\hline Site & $\begin{array}{l}\text { Age in } \\
2009(y r)\end{array}$ & $\begin{array}{l}\text { Size } \\
\text { (ha) }\end{array}$ & Byplants & $\begin{array}{l}\text { Ordinance } \\
\text { Survey Map }\end{array}$ & Groups & $\begin{array}{l}\text { No. } \\
2009\end{array}$ & $\begin{array}{l}\text { No. } \\
2010\end{array}$ \\
\hline \multirow[t]{2}{*}{ S1 } & \multirow[t]{2}{*}{36} & \multirow[t]{2}{*}{0.4} & \multirow[t]{2}{*}{ None } & \multirow[t]{2}{*}{$4609 / 1$} & Diplopoda & 33 & 64 \\
\hline & & & & & Chilopoda & 3 & 0 \\
\hline \multirow[t]{2}{*}{ Total } & & & & & Diplopoda & 33 & 64 \\
\hline & & & & & Chilopoda & 3 & 0 \\
\hline \multicolumn{8}{|c|}{ (d) Fallow ground } \\
\hline Site & $\begin{array}{l}\text { Age in } \\
2009(y r)\end{array}$ & $\begin{array}{l}\text { Size } \\
\text { (ha) }\end{array}$ & Byplants & $\begin{array}{l}\text { Ordinance } \\
\text { Survey Map }\end{array}$ & Groups & $\begin{array}{l}\text { No. } \\
2009\end{array}$ & $\begin{array}{l}\text { No. } \\
2010\end{array}$ \\
\hline \multirow[t]{2}{*}{$\mathrm{F} 1$} & 23 & 1.4 & None & $4609 / 2$ & Diplopoda & 184 & 97 \\
\hline & & & & & Chilopoda & 2 & 2 \\
\hline \multirow[t]{2}{*}{$\mathrm{F} 2$} & 30 & 1.9 & None & $4509 / 4$ & Diplopoda & 87 & 323 \\
\hline & & & & & Chilopoda & 1 & 6 \\
\hline \multirow[t]{2}{*}{ Total } & & & & & Diplopoda & 271 & 420 \\
\hline & & & & & Chilopoda & 3 & 8 \\
\hline \multirow{2}{*}{$\begin{array}{l}\text { Total } \\
\text { (a)-(d) }\end{array}$} & & & & & Diplopoda & 1659 & 3417 \\
\hline & & & & & Chilopoda & 37 & 111 \\
\hline
\end{tabular}

${ }^{*} 1$ of 3 traps lost.

succession-related development (Dunger and Voigtländer, 2009). Topp et al. (1992) observed a frequent mix of synanthropic or eurytopic woodland Diplopoda (e.g. Polydesmus denticulatus, Julus scandinavius, Craspedosoma rawlinsi, and Allajulus nitidus) while their putative role as indicators of succession-related parameters remained equivocal (Scheu and Schulz, 1996; Dunger and Voigtländer, 2009). Whereas "even soil invertebrates of similar trophic groups appear to respond very differently to successional changes" (Scheu and Schulz, 1996), "myriapods are good indicators of biological soil quality and are reliable and easy to use" (Dunger and Voigtländer, 2009).

In the present study we report on the species composition and abundance of Diplopoda and Chilopoda over the run of succession in Western German (North Rhine-Westphalian) beech and coniferous forests (Douglas fir, spruce) as compared to fallow ground. Overall, soils were "rich" and predominantly consisted of loam. For the studied area, groundbeetle data were elaborated showing a constant size distribution of Carabidae, thus indicating rather modest differences in degradation (Schreiner and Schwerk, 2011; Schreiner et al., 2011). The basic aim of this paper is to analyze the impact of the different habitat types and age of the forest stands on myriapod assemblages. We predict a dominant influence of the habitat types. Moreover, we assume a change in the abundance of certain myriapod species with increasing age of the forest stands. We will especially focus on the positive relationship between the age of plantations and Julusscandinavius numbers brought forward by Topp et al. (1998).
Effects may also be expected with regard to the sex distribution in different forest types. Our work, next to contributing to an overview of the millipede and centipede inventory of North Rhine-Westphalia (Decker et al., 2009; Hannig et al., 2009; Decker and Hannig, 2008, 2009, 2010, 2011), shall therefore help to identify possible bioindicators of succession in the subphylum of Myriapoda.

\section{Materials and methods}

In Western German forests (Ruhr valley between Herdecke and Hattingen, North Rhine-Westphalia), different successional stages were represented by 21 study sites of variable age (14 beech stands: $1-165 \mathrm{yr}$, 4 Douglas-fir stands: $1-30 \mathrm{yr}$, 1 spruce stand: $36 \mathrm{yr}$, and 2 fallow-ground sites: 23 and $30 \mathrm{yr}$; Table 1); all but the fallow-ground sites based on loam soil and had a history of forestry. They were studied over 2 complete vegetation periods (April-October each in 2009 and 2010). Millipedes and centipedes (Myriapoda: Diplopoda, Chilopoda) were collected by pitfall traps (Barber, 1931) and occasional manual sampling (in order to complete the species inventory), and determined to the species. In 2009 only, animals were determined to their sexes in order to study changes in activity densities between males and females. For reasons of comparability, only the ground-trapping results were further analyzed and used as the data base for our Tables and Figures. 
a
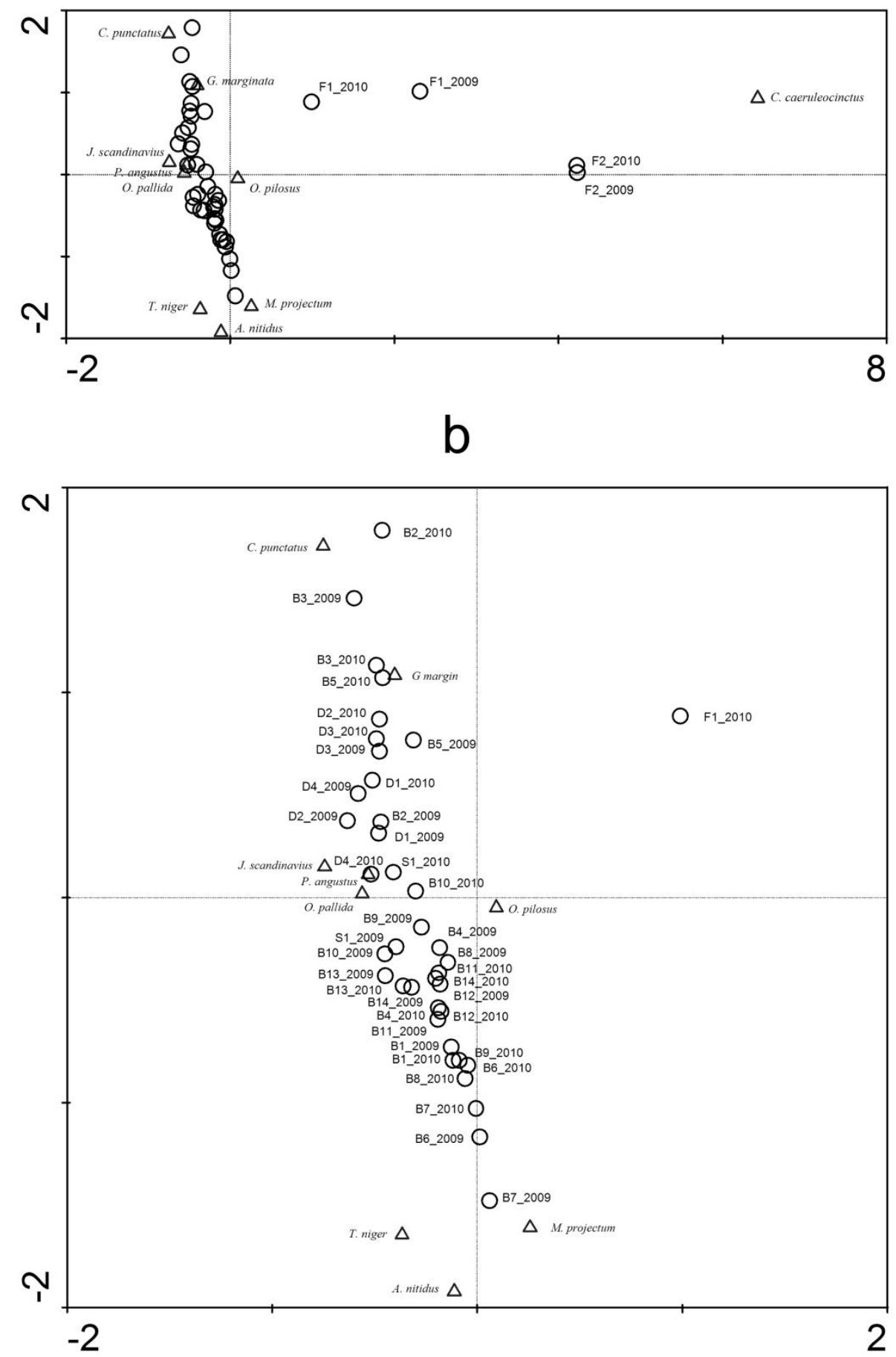

Figure 1. Indirect gradient analysis (CA): biplot of species and study sites. Complete diagram (a) and detail of left part of the diagram (b).

Three traps were placed in each site by keeping a distance of 5-10 $\mathrm{m}$ between individual traps. Boundary effects were avoided by placing the traps at least $20 \mathrm{~m}$ away from the site's edges (den Boer, 1977).
Collected Myriapoda were stored in commercial EtOH $70 \% v / v$ before determination.

Indirect gradient analysis (correspondence analysis, CA) was carried out using the CANOCO for Windows software package, version 4.5 (ter Braak, 1987; ter Braak and 


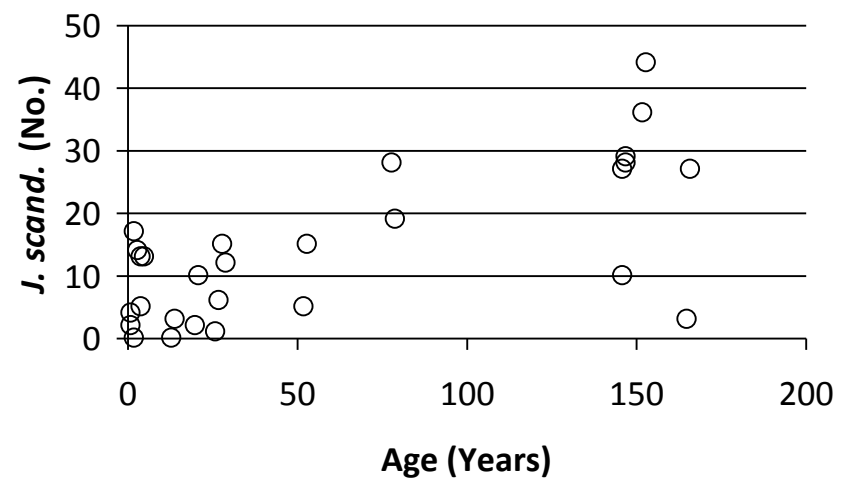

Figure 2. Relationship between age of the beech stands and number of J. scandinavius individuals (combined 2009 and 2010); $r=$ $0.949, p<0.001$.

Šmilauer, 2002), to describe patterns of faunal change and to get information about determining factors. Detrended correspondence analysis (DCA) was performed in advance to select the appropriate statistical model (ter Braak and Prentice, 1988). Hence, CA was done using scaling on inter-sample distances and Hill's scaling. Dominance values of all diplopod species on our study sites were used. Species data were not transformed. None of the species or samples was deleted or weighted. Biplots on species and samples were created under species-weight-range adjustment in a way to leave 10 species with the largest impact on the results for display (ter Braak and Šmilauer, 2002).

Possible correlations between selected parameters (number of individuals, male/female ratio) and age of the stands were tested using the Spearman rank correlation coefficient (Sachs, 1984) as calculated using the SPSS 9.0 software package. Diplopod-sex distribution between forest types was analyzed employing the $\chi^{2}$ test (Sachs, 1984).

\section{Results}

A total of 5224 Myriapoda (5076 Diplopoda and 148 Chilopoda) were found in pitfall traps in beech (14 sites) and coniferous forest stands ( 5 sites) as well as on fallow ground ( 2 sites) in 2009 and 2010 (Table 1a-d). The numbers of individuals collected on some study sites suffered from occasional vandalism (e.g. 2009: site B9; 2010: sites B6 and F1) or loss of traps (as indicated in Table 1). In addition, 41 animals (32 Diplopoda, 9 Chilopoda) were caught manually on site B10 in autumn 2009. Except for one chilopod species (Geophilus electricus, Linnaeus, 1758) all hand-caught myriapod species also occurred in ground traps.

Generally, catching results approximately doubled in 2010 as compared to 2009 while Diplopoda were caught far more frequently than Chilopoda in every site and year (Table 1a-d). Strong fluctuation of individual counts occurred between the sites (no overall trend, large standard deviations, data not shown).
Due to the small number of Chilopoda caught we focused on Diplopoda for further analyses: in the correspondence analysis (CA, Fig. 1), the first and second ordination axes together explained $52.7 \%$ of the total variance (first axis: $31.5 \%$, second axis: $21.2 \%$ ). The first axis, with the fallowground sites located on the right-hand side clearly separated from the forest stands, indicates an important influence of the habitat type on the dominance of certain diplopod species. E.g. Cylindroiulus caeruleocinctus (Wood, 1864), which was found on open land only, is located on the far right-hand side of the diagram, whereas C. punctatus (Leach, 1815) and Allajulus nitidus (Verhoeff, 1891), which were hardly found on open land, are located on the left-hand side. The second ordination axis, however, shows recognizable separation with regard to the stage of succession, with the youngest beech stand and the coniferous stands located in the top part of the diagram. Accordingly, A. nitidus, which was not found in coniferous forests, is located on the bottom of the diagram, C. punctatus on the top. Julus scandinavius (Latzel, 1884), known for its affinity to aged plantations, appears in a central position along the second axis.

As is depicted in Table 2 there was no obvious trend in most of Diplopoda species over the run of beech succession in 2009 and 2010, respectively. However, with regard to $J$. scandinavius numbers a significant increase was observed while forest stands grew older (2010 data: $r=0.775$, $p<0.01)$. This relationship was even more pronounced when combining both years of observation $(r=0.949, p<0.001$, Fig. 2). Results were confirmed by looking at the dominance of $J$. scandinavius in beech stands in $2010(r=0.656$, $p<0.05)$ as well as 2009 and 2010 combined $(r=0.932$, $p<0.001$, data not shown).

In analogy to Table 2, Table 3 shows the situation in coniferous forests (Douglas fir, spruce) and on fallow ground. Here, no clear trend was recognized with regard to different stages of succession, this includes the data on J. scandinavius.

Finally, when analyzing the sex distribution of millipedes in 2009 (data not shown) we detected a significant difference between fallow ground and coniferous forests with regard to sex dominance $\left(\chi^{2}\right.$ test: $\left.p<0.01\right)$. In coniferous forests more male than female animals were trapped while females dominated over males on open land. In our deciduous sites (beech), however, findings were equivocal.

\section{Discussion}

Since we did not follow succession in several forest stands over a long time but used different stands of variable age over a 2-yr observation period, we had to check for site comparability beforehand. Although we could not trace all geological or botanical prerequisites in great detail - some sites were also frequently used for recreational purposes in our densely populated area - all our forest sites at least had, next to the 
Table 2. Number of Diplopoda individuals by species in beech habitats (B sites): 2009/2010.

\begin{tabular}{|c|c|c|c|c|c|c|c|c|c|c|c|c|c|c|c|}
\hline \multirow[t]{2}{*}{ No. } & \multirow[t]{2}{*}{ Species } & \multicolumn{14}{|c|}{ Sites } \\
\hline & & B1 & B2 & B3 & B4 & B5 & B6 & B7 & B8 & B9 & B10 & B11 & B12 & B13 & B14 \\
\hline 1 & $\begin{array}{l}\text { Glomeris marginata } \\
\text { Villers (1789) }\end{array}$ & $26 / 56$ & $3 / 5$ & $66 / 263$ & $24 / 33$ & $28 / 40$ & $6 / 23$ & $3 / 14$ & $18 / 24$ & $9 / 17$ & $11 / 127$ & $54 / 73$ & $50 / 24$ & $-/ 8$ & $6 / 38$ \\
\hline 2 & $\begin{array}{l}\text { Proteroiulus fuscus } \\
\text { Am Stein (1857) }\end{array}$ & $-1-$ & $-1-$ & $-1-$ & $-1-$ & $-1-$ & $-1-$ & $-1-$ & $-1-$ & $-1-$ & $-1-$ & $-1-$ & $-1-$ & $-1-$ & $-/ 1$ \\
\hline 3 & $\begin{array}{l}\text { Allajulus nitidus } \\
\text { Verhoeff (1891) }\end{array}$ & $2 /-$ & $-1-$ & $-1-$ & $-/ 1$ & $-1-$ & $1 /-$ & $6 /-$ & $-/ 7$ & $-/ 1$ & $-1-$ & $36 / 9$ & $1 / 3$ & $1 /-$ & $3 / 1$ \\
\hline 4 & $\begin{array}{l}\text { Cylindroiulus britannicus } \\
\text { Verhoeff (1891) }\end{array}$ & $-1-$ & $-1-$ & $7 / 4$ & $-1-$ & $-1-$ & $-1-$ & $-1-$ & $-1-$ & $-1-$ & $-1-$ & $-1-$ & $-1-$ & $-1-$ & $-1-$ \\
\hline 5 & $\begin{array}{l}\text { C. caeruleocinctus } \\
\text { Wood (1864) }\end{array}$ & $-1-$ & $-1-$ & $-1-$ & $-1-$ & $-1-$ & $1 / 1$ & $-1-$ & $1 /-$ & $-1-$ & $-1-$ & $-1-$ & $-1-$ & $-1-$ & $-/ 1$ \\
\hline 6 & $\begin{array}{l}\text { C. punctatus } \\
\text { Leach (1815) }\end{array}$ & $1 / 8$ & $2 / 4$ & $87 / 114$ & $1 / 1$ & $1 / 5$ & $-/ 1$ & $-/ 8$ & $-/ 9$ & $3 / 6$ & -12 & $-/ 3$ & $-/ 1$ & $-1-$ & $15 / 49$ \\
\hline 7 & $\begin{array}{l}\text { Julus scandinavius } \\
\text { Latzel (1884) }\end{array}$ & $2 / 17$ & $4 /-$ & $14 / 5$ & $13 / 13$ & -13 & $2 / 10$ & $1 / 6$ & $15 / 12$ & $5 / 15$ & $28 / 19$ & $27 / 28$ & $10 / 29$ & $36 / 44$ & $3 / 27$ \\
\hline 8 & $\begin{array}{l}\text { Megaphyllum projectum } \\
\text { Verhoeff (1894) }\end{array}$ & $40 / 135$ & $2 /-$ & $-1-$ & $29 / 40$ & $1 /-$ & $25 / 54$ & $54 / 106$ & $24 / 105$ & $11 / 75$ & $10 / 47$ & $66 / 89$ & $55 / 59$ & $12 / 28$ & $15 / 134$ \\
\hline 9 & $\begin{array}{l}\text { Ophyiulus pilosus } \\
\text { Newport (1842) }\end{array}$ & $3 / 8$ & $-1-$ & $-/ 10$ & $6 / 2$ & 7/- & $4 / 2$ & $1 /-$ & $3 / 10$ & $1 / 11$ & $-/ 6$ & $21 / 15$ & $1 / 4$ & $4 / 4$ & $-/ 3$ \\
\hline 10 & $\begin{array}{l}\text { Tachypodoiulus niger } \\
\text { Leach (1814) }\end{array}$ & $21 / 58$ & $-1-$ & $-/ 13$ & $1 / 20$ & $-1-$ & $23 / 21$ & $15 / 16$ & $4 / 23$ & $2 / 14$ & $10 / 34$ & $15 / 15$ & $13 / 3$ & $7 / 10$ & $17 / 22$ \\
\hline 11 & $\begin{array}{l}\text { Unciger foetidus } \\
\text { C. L. Koch (1838) }\end{array}$ & $-1-$ & $-1-$ & $-1-$ & $-1-$ & $-1-$ & $-1-$ & $-1-$ & $-1-$ & $-1-$ & $-/ 2$ & $-1-$ & $-1-$ & $-1-$ & $-1-$ \\
\hline 12 & $\begin{array}{l}\text { Craspedosoma rawlinsi } \\
\text { Leach (1815) }\end{array}$ & $-/ 1$ & $-1-$ & $-1-$ & $-1-$ & $-1-$ & $-1-$ & $-1-$ & $-1-$ & $-/ 1$ & $1 / 1$ & $4 /-$ & $3 /-$ & $-1-$ & $-/ 3$ \\
\hline 13 & $\begin{array}{l}\text { Chordeuma sylvestre } \\
\text { C. L. Koch (1847) }\end{array}$ & $-1-$ & $-1-$ & $-/ 1$ & $-1-$ & $-1-$ & $-1-$ & $1 /-$ & $-1-$ & $-/ 1$ & $-/ 2$ & $4 /-$ & $2 /-$ & $-1-$ & $1 /-$ \\
\hline 14 & $\begin{array}{l}\text { Orthochordeumella pallida } \\
\text { Rothenbühler (1899) }\end{array}$ & $3 /-$ & $-/ 1$ & $-1-$ & $2 /-$ & $-1-$ & $-/ 1$ & $-1-$ & $1 / 3$ & $1 / 6$ & $-/ 6$ & $-/ 2$ & $4 / 3$ & $3 /-$ & $-/ 11$ \\
\hline 15 & $\begin{array}{l}\text { Polydesmus angustus } \\
\text { Latzel (1884) }\end{array}$ & $1 / 14$ & $-1-$ & $3 / 8$ & $1 / 1$ & $1 / 1$ & $-1-$ & $1 / 10$ & $4 / 7$ & $3 / 3$ & $3 / 5$ & $20 / 24$ & $8 / 4$ & $7 / 11$ & $1 / 25$ \\
\hline 16 & $\begin{array}{l}\text { P. denticulatus } \\
\text { C. L. Koch (1847) }\end{array}$ & $1 /-$ & $-1-$ & $-1-$ & $-1-$ & $1 /-$ & $-1-$ & $-/ 2$ & $1 /-$ & $-1-$ & $1 / 2$ & $3 /-$ & $-/ 4$ & $-1-$ & $-/ 12$ \\
\hline \multirow[t]{3}{*}{17} & $\begin{array}{l}\text { P. testaceus } \\
\text { C. L. Koch (1847) }\end{array}$ & $-1-$ & $-1-$ & $-1-$ & $-1-$ & $-1-$ & $-1-$ & $-1-$ & $-/-$ & $-/ 1$ & $-1-$ & $-1-$ & $-1-$ & $-1-$ & $-1-$ \\
\hline & Undet. Julidae & $-1-$ & $-/ 2$ & $3 /-$ & $-1-$ & $-1-$ & $-1-$ & $-1-$ & $-1-$ & $-1-$ & $-1-$ & $-1-$ & $-1-$ & $-1-$ & $-1-$ \\
\hline & Total & $100 / 297$ & $11 / 12$ & $180 / 418$ & $77 / 111$ & $39 / 49$ & $62 / 113$ & $82 / 162$ & $71 / 200$ & $35 / 151$ & $64 / 253$ & $250 / 258$ & $147 / 134$ & $70 / 105$ & $61 / 327$ \\
\hline
\end{tabular}

loam-based soil composition, a common history of forestry and a similar size distribution in selected carabid species (Schreiner and Schwerk, 2011; Schreiner et al., 2011).

The fact that our catching results more than doubled from 2009 to 2010 may be attributed to various (yet unexamined) beneficial factors effective over the previous years of hemimetabolous development. It may also be due to the rainy 2010 summer that possibly led to increased Myriapoda activity on the ground. According to our view, it had no relevant influence on the test statistics. The very low number of centipedes caught may be connected to the artificial forest structure usually found in commercial forests as Balkenhol et al. (2006) observed the absence of stenotopic forest Chilopoda in stands on recultivated soil. When supplementing our pitfall-trapping results by occasional manual catches (which should be intensified and standardized in further studies) we were able to detect one individual of Geophilus electricus (Linnaeus, 1758) in a 78-yr-old beech stand, which was a rare event for North Rhine-Westphalian forests.

In the group of Diplopoda, as was expected, we trapped mostly eurytopic forest species. The habitat-type preferences observed for some species not only match the literature data very well (Spelda, 1999; Hauser and Voigtländer, 2009), they are also the most important factor influencing the formation of diplopod assemblages. In contrast to the situation in carabid beetles on the same study sites (A. Schreiner, unpublished data), the habitat type has even a greater impact on diplopod variance than the successional stage of the habitat.

Our significant result concerning Julus scandinavius (Latzel, 1884) as a bioindicator of deciduous-forest succession confirms findings of Topp et al. (1998), who mentioned already in 1998 that, after planting measures on postindustrial soil, a tendency of increasing individual counts was observed for J. scandinavius only. J. scandinavius also reacted positively to introducing forest topsoil (Topp et al., 1998). According to our data depicted in Fig. 2, however, it is impossible to judge on the underlying mathematical function by which $J$. scandinavius multiplies in ageing forests. Corresponding to the situation in carabid beetles (Schreiner and Schwerk, 2012) and many other biological models (Turchin, 2003) one could suggest that the underlying curve follows a logistic growth function, but a positive linear relationship between the age of beech stands and number of J. scandinavius individuals seems just as well possible when, e.g. suggesting a positive correlation between diplopod numbers and the amount of available carbon. Scheu and Schulz (1998) 
Table 3. Number of Diplopoda individuals by species in coniferous forest habitats (D and S sites) and on fallow ground (F sites): 2009/2010.

\begin{tabular}{|c|c|c|c|c|c|c|c|c|}
\hline \multirow[t]{2}{*}{ No. } & \multirow[t]{2}{*}{ Species } & \multicolumn{5}{|c|}{ Sites } & \multirow[b]{2}{*}{$\mathrm{F} 1$} & \multirow[b]{2}{*}{$\mathrm{F} 2$} \\
\hline & & D1 & D2 & D3 & D4 & S1 & & \\
\hline 1 & $\begin{array}{l}\text { Glomeris marginata } \\
\text { Villers (1789) }\end{array}$ & $2^{*} / 20^{*}$ & $7 * / 140$ & $16 / 33$ & $14 / 18$ & $3 / 17$ & $83 / 54$ & $-/-$ \\
\hline 2 & $\begin{array}{l}\text { Allajulus nitidus } \\
\text { Verhoeff (1891) }\end{array}$ & $-{ }^{*} /-^{*}$ & $-*$ & $-/-$ & $-1-$ & $-/-$ & $3 /-$ & $-/-$ \\
\hline 3 & $\begin{array}{l}\text { Cylindroiulus britannicus } \\
\text { Verhoeff (1891) }\end{array}$ & $--^{*}-^{*}$ & $-* /-$ & $-/-$ & $-1-$ & $-1-$ & $-/ 1$ & $-/-$ \\
\hline 4 & $\begin{array}{l}\text { C. caeruleocinctus } \\
\text { Wood (1864) }\end{array}$ & $--^{*} /-^{*}$ & $-* /-$ & $-/-$ & $-1-$ & $-/-$ & $72 / 20$ & $56 / 207$ \\
\hline 5 & $\begin{array}{l}\text { C. punctatus } \\
\text { Leach (1815) }\end{array}$ & $-{ }^{*} / 1^{*}$ & $1^{*} / 8$ & $-/-$ & $-/ 4$ & $4 / 6$ & $2 / 2$ & $-/-$ \\
\hline 6 & $\begin{array}{l}\text { Julus scandinavius } \\
\text { Latzel (1884) }\end{array}$ & $5^{*} / 14^{*}$ & $20 * / 30$ & $6 / 11$ & $20 / 20$ & $9 / 14$ & $3 / 6$ & $-/-$ \\
\hline 7 & $\begin{array}{l}\text { Megaphyllum projectum } \\
\text { Verhoeff (1894) }\end{array}$ & $-{ }^{*} / 1^{*}$ & $-{ }^{*} /-$ & $-/-$ & $-/ 2$ & $7 / 12$ & $-1-$ & $31 / 95$ \\
\hline 8 & $\begin{array}{l}\text { Ommatoiulus sabulosus } \\
\text { Linnaeus (1758) }\end{array}$ & $-{ }^{*} /-^{*}$ & $-* /-$ & $-1-$ & $-1-$ & $-1-$ & $-1-$ & $-/ 1$ \\
\hline 9 & $\begin{array}{l}\text { Ophyiulus pilosus } \\
\text { Newport (1842) }\end{array}$ & $2^{*} / 1^{*}$ & $-* / 1$ & $1 /-$ & $1 /-$ & $1 /-$ & $12 / 5$ & $-/ 18$ \\
\hline 10 & $\begin{array}{l}\text { Tachypodoiulus niger } \\
\text { Leach (1814) }\end{array}$ & $-{ }^{*} /-^{*}$ & $-* /-$ & $-1-$ & $-/ 12$ & $5 / 3$ & $-1-$ & $-/ 2$ \\
\hline 11 & $\begin{array}{l}\text { Orthochordeumella pallida } \\
\text { Rothenbühler (1899) }\end{array}$ & $--^{*} /-^{*}$ & $-* / 1$ & $-/ 1$ & $-1-$ & $3 /-$ & $-1-$ & $-/-$ \\
\hline 12 & $\begin{array}{l}\text { Polydesmus angustus } \\
\text { Latzel (1884) }\end{array}$ & $-{ }^{*} / 4^{*}$ & $7^{*} / 13$ & $3 / 4$ & $1 /-$ & $1 / 12$ & $2 / 9$ & $-/-$ \\
\hline 13 & $\begin{array}{l}\text { P. denticulatus } \\
\text { C. L. Koch (1847) }\end{array}$ & $-{ }^{*} / 1^{*}$ & $-* / 3$ & $-/-$ & $-1-$ & $-1-$ & $-1-$ & $-1-$ \\
\hline & Undet. Julidae & $--^{*} /-^{*}$ & $-* /-$ & $-/-$ & $-1-$ & $-1-$ & $7 /-$ & $-/-$ \\
\hline & Total & $9^{*} / 42^{*}$ & $35 * / 196$ & $26 / 49$ & $36 / 56$ & $33 / 64$ & $184 / 97$ & $87 / 323$ \\
\hline
\end{tabular}

* 1 of 3 traps lost.

eluded to a formation of "carbon-rich topsoil in later successional stages" and pointed out a suspected accumulation of soil carbon due to the "occurrence of woody debris and recalcitrant leaf litter of beech trees" and conditioning by earthworm species of the upper mineral soil. According to Szyszko et al. (2003), the increase of carbon content in the mineral soil of ageing forests may well be linear. However, more data (more sites or a prolonged observation period) are necessary to elucidate the complex interdependencies of certain diplopods and soil quality in deciduous-forest ecosystems. This includes the study of sex-specific features of different habitat types. In this respect, however, it is difficult to evaluate myriapod-sex data pooled from different species, because some species are - also a result of this work - highly habitat-type-specific. Larger numbers of individuals of selected species will be required for proper statistics.

Pitfall traps may be biased with respect to displaying male-to-female ratios of arthropods. Changes of activity patterns (as observed by different proportions of males and females in pitfall traps) in relation to the feeding state have been previously shown for different carabid species (e.g. Fournier and Loreau, 2001, 2002; Szyszko et al., 2004). These changes may even be sex-specific (Szyszko et al., 2004). Such changes in locomotory behavior may also occur in certain diplopods as our first results are encouraging.

In conclusion, Myriapoda catching results in Western German forests on loam soil increased markedly from 2009 to 2010 while Diplopoda were caught far more frequently than Chilopoda. Generally, the habitat type had a greater impact on the species variance than the stage of succession. Although strong fluctuation of abundance of many species occurred between the sites, Julus scandinavius (Latzel, 1884) may be a good candidate for a bioindicator of deciduousforest succession. More data are needed to confirm and augment these results.

Acknowledgements. The authors wish to thank M. Foellmer, J. Szyszko, and a second reviewer for their valuable comments, which significantly improved the quality of this paper. Communication No. 385 of the Laboratory of Evaluation and Assessment of Natural Resources, Warsaw University of Life Sciences - SGGW. 
Edited by: M. Foellmer

Reviewed by: J. Szyszko and another anonymous referee

\section{References}

Balkenhol, B., Brunk, I., Vogel, J., Voigtländer, K., and Xylander, W. E. R.: Sukzession der Staphyliniden- und ChilopodenCoenosen einer Roteichen-Chronosequenz im Vergleich zu Offenlandflächen und Traubeneichenwäldern, in: Biodiversität und Sukzession in der Niederlausitzer Bergbaufolgelandschaft, edited by: Bröring, U. and Wiegleb, G., Books on Demand $\mathrm{GmbH}$, Norderstedt, 45-56, 2006.

Barber, H. S.: Traps for cave inhabiting insects, J. Mitchel. Soc., 46, 259-266, 1931.

Decker, P. and Hannig, K.: Erstnachweis von Glomeris pustulata Latreille, 1804 (Diplopoda: Glomerida) für NordrheinWestfalen, Schubartiana, 3, 53-56, 2008.

Decker, P. and Hannig, K.: Die Hundert- und Tausendfüßer (Chilopoda, Diplopoda) des Venner Moores bei Senden (Nordrhein-Westfalen, Kreis Coesfeld), Natur und Heimat, 69, 59-67, 2009.

Decker, P. and Hannig, K.: Nanogona polydesmoides (LEACH, 1815) - New for the German fauna (Diplopoda, Chordeumatida, Craspedosomatidae), Bulletin Brit. Myriapod \& Isopod Group, 24, 33-34, 2010.

Decker, P. and Hannig, K.: Checkliste der Hundert- und Tausendfüßer (Myriapoda: Chilopoda, Diplopoda) NordrheinWestfalens, Abhandlungen Westfäl. Mus. Naturkunde, 73, 3-48, 2011.

Decker, P., Schmidt, C., and Hannig, K.: Die Hundertfüßer und Tausendfüßer (Myriapoda, Chilopoda, Diplopoda) des Truppenübungsplatzes Haltern-Borkenberge (Kreise Coesfeld und Recklinghausen), in: Die Tiere, Pflanzen und Pilze des Truppenübungsplatzes Borkenberge, edited by: Hannig, K., Olthoff, M., Wittjen, K., and Zimmermann, T., Abhandlungen Westfäl. Mus. Naturkunde, 71, 469-478, 2009.

den Boer, P. J.: Dispersal power and survival. Carabids in a cultivated countryside, Misc. Papers Landbouwhogeschool Wageningen 14, edited by: Veenmann, H. and Zonen, B. V., Wageningen, 1977.

Dunger, W. and Voigtländer, K.: Succession of Myriapoda in primary colonization of reclaimed land, in: Proc. $7^{\text {th }}$ Int. Congress Myriapodol., edited by: Minelli, A., Brill, E. J., Leiden, 219-227, 1990.

Dunger, W. and Voigtländer, K.: Soil fauna (Lumbricidae, Collembola, Diplopoda and Chilopoda) as indicators of soil ecosubsystem development in post-mining sites of Eastern Germany - a review, Soil Organisms, 81, 1-51, 2009.

Fournier, E. and Loreau, M.: Activity and satiation state in Pterostichus melanarius: an experiment in different agricultural habitats, Ecol. Entomol., 26, 235-244, 2001.

Fournier, E. and Loreau, M.: Foraging activity of the carabid beetle Pterostichus melanarius Ill. in field margin habitats, Agr. Ecosyst. Environ., 89, 253-259, 2002.

Hannig, K., Kerkering, C., Schäfer, P., Decker, P., Sonnenburg, H., Raupach, M., and Terlutter, H.: Kommentierte Artenliste zu ausgewählten Wirbellosengruppen (Coleoptera: Carabidae, Hygrobiidae, Haliplidae, Noteridae, Dytiscidae, Hydrophilidae; Heteroptera; Hymenoptera: Formicidae; Crustacea: Isopoda; Myri- apoda: Chilopoda, Diplopoda) des NSG "Emsdettener Venn" im Kreis Steinfurt (Nordrhein-Westfalen), Natur und Heimat, 69, 132, 2009.

Hauser, H. and Voigtländer, K.: Doppelfüßer (Diplopoda) Ostdeutschlands, 6th Edn., Dtsch. Jugendbund Naturbeobachtung, 2009.

Koivula, M. J.: Useful model organisms, indicators, or both? Ground beetles (Coleoptera, Carabidae) reflecting environmental conditions, in: Carabid beetles as bioindicators: biogeographical, ecological and environmental studies, edited by: Kotze, D. J., Assmann, T., Noordijk, J., Turin, H., and Vermeulen, R., ZooKeys, 100, 287-317, 2011.

Neumann, U.: Die Sukzession der Bodenfauna (Carabidae (Coleoptera), Diplopoda und Isopoda) in den forstlich rekultivierten Gebieten des Rheinischen Braunkohlenreviers, Pedobiologia, 11, 193-226, 1971.

Pott, R.: Die Pflanzengesellschaften Deutschlands, 2nd ext. Edn., Ulmer, Stuttgart, 1995.

Sachs, L.: Angewandte Statistik: Anwendung statistischer Methoden, 6th Edn., Springer, Berlin, Heidelberg, New York, Tokyo, 1984.

Scheu, S. and Schulz, E.: Secondary succession, soil formation and development of a diverse community of oribatids and saprophagous soil macro-invertebrates, Biodivers. Conserv., 5, 235-250, 1996.

Schreiner, A.: Large carabids (Coleoptera: Carabidae) prevail in ageing forests: Mean Individual Biomass and Carabus dominance as indicators of succession in North Rhine-Westphalian beech forests, Angewandte Carabidologie, 9, 51-55, 2011.

Schreiner, A. and Schwerk, A.: Standard deviation of carabid size in Western German forest succession - a complex picture, Baltic J. Coleopterol., 11, 25-31, 2011.

Schreiner, A. and Schwerk, A.: Does the Mean Individual Biomass (MIB) of carabids as a bioindicator of forest succession follow a logistic function? - Examples from Western German beech and Polish Scots pine forests, Baltic J. Coleopterol., in review, 2012.

Schreiner, A., Schreiner, W., and Schwerk, A.: Western German beech and Douglas fir stands in forest succession research: Focus on Carabus violaceus, in: Opportunity for economic growth and biodiversity protection in rural areas - spatial management and forestry, edited by: Szyszko, J., Bodzenta, M., Dymitryszyn, I., and Jojczyk, A., WULS-SGGW Press, Warsaw, 63-68, 2011.

Schwerk, A.: Model of the rate of succession of epigeic carabid beetles (Coleoptera: Carabidae) on degraded areas, Habilitation thesis, Instytut Badawczy Leśnictwa, Sêkocin Stary, 2008.

Schwerk, A. and Szyszko, J.: Increase of mean individual biomass (MIB) of Carabidae (Coleoptera) in relation to succession in forest habitats, Wiad. Entomol., 26, 195-206, 2007.

Spelda, J.: Verbreitungsmuster und Taxonomie der Chilopoda und Diplopoda Südwestdeutschlands. Diskriminanzanalytische Verfahren zur Trennung von Arten und Unterarten am Beispiel der Gattung Rhymogona Cook, 1896 (Diplopoda: Chordeumatida: Craspedosomatidae) - Part 2., Ph.D. dissertation, Ulm University Press, Ulm, 1999.

Szyszko, J.: Methods of macrofauna investigations, in: The process of forest soil macrofauna formation after afforestation of farmland, edited by: Szujecki, A., Mazur, S., Perliñski, S., and Szyzsko, J., Warsaw Agricultural University Press, Warsaw, 1016,1983 . 
Szyszko, J., Płatek, K., Dyjak, R., Michalski, A. and Sałek, P.: Określenie modelowego projektu w dziedzinie wzrostu pochłaniania gazów cieplarniarnych przez zalesienie nizinnych terenów nieleśnych na obszarze kraju, Research report, Laboratory of Evaluation and Assessment of Natural Resources, WULSSGGW Press, Warsaw, 2003.

Szyszko, J., Gryuntal, S., and Schwerk, A.: Differences in locomotory activity between male and female Carabus hortensis (Coleoptera: Carabidae) in a pine forest and a beech forest in relation to feeding state, Environ. Entomol., 33, 1442-1446, 2004.

ter Braak, C. J. F.: CANOCO - A FORTRAN program for canonical community ordination by [partial][detrended][canonical] correspondence analysis, principal components analysis and redundancy analysis (version 2.1), DLO Agricultural Mathematics Group, Wageningen, 1987.

ter Braak, C. J. F. and Prentice, I. C.: A theory of gradient analysis, Adv. Ecol. Res., 18, 271-317, 1988.

ter Braak, C. J. F. and Šmilauer, P.: CANOCO reference manual and CanoDraw for Windows user's guide: Software for canonical community ordination (version 4.5), Microcomputer Power, Ithaca, 2002.
Topp, W.: Der Einfluss von Rekultivierungsmaßnahmen auf die Bodenfauna, in: Braunkohlentagebau und Rekultivierung - Landschaftsökologie, Folgenutzung, Naturschutz, edited by: Pflug, W., Springer, Berlin, 325-336, 1998.

Topp, W., Gemesi, O., Gruning, C., Tasch, P., and Zhou, H. Z.: Colonization of soil fauna in afforested coal mined areas in the Rhineland, Zool. Jb. Syst., 119, 505-533, 1992.

Turchin, P.: Complex population dynamics: a theoretical/empirical synthesis, Princeton University Press, Princeton, 2003.

Voigtländer, K. and Balkenhol, B.: Studies on millipede assemblages (Myriapoda, Diplopoda) as influenced by habitat qualities of afforested mine sites, Proc. 13th Int. Congress Myriapodol. Norwegean J. Entomol., 53, 345-360, 2006.

Zulka, K. P.: Überflutung als ökologischer Faktor: Verteilung, Phänologie und Anpassung der Diplopoda, Lithobiomorpha und Isopoda in den Flußauen der March, Ph.D. dissertation, Vienna University Press, Vienna, 1991. 